\title{
Factors influencing the quality of design documentation on South African civil engineering projects
}

\author{
E Akampurira, A Windapo
}

\section{INTRODUCTION}

Construction projects typically go through four phases, namely planning, design, construction and operation and maintenance. Linked to these phases are three crucial role players: the client who requires an engineering solution to a problem, the designer responsible for defining and detailing the solution to the client's problem, and the contractor who is in charge of the execution of the works as detailed by the designer (Emmitt 2007).

The focus of this study is on the set of design documentation that is provided to the contractor to facilitate the execution of the construction works. This documentation includes engineering drawings, bills of quantities, standard specifications, project specifications, services information, materials report, site-specific geotechnical reports and topographical surveys, among others. These documents are a key product of the design process and aim to provide sufficient detail to enable the contractor to efficiently implement the construction phase of the project (Emmitt 2007; Tilley et al 1999).

Good quality design documentation is of particular importance considering the distinct role the design documents play in communicating the design intent (Emmitt 2007) and enabling the estimation of cost (Davis et al 2009). Wahedi (2016) further points out that during the construction phase, the design documents serve various purposes, including serving as legal documents, coordinating the works and as a management tool for resource allocation. Researchers have also repeatedly identified the critical role that good quality design documentation plays in attaining the construction project objectives of quality, cost and time (Chua et al 1999; Yong \& Mustaffa 2011).

However, poor quality design documentation has been identified as an ongoing concern in the construction industry in a number of countries: Australia (Tilley et al 1997; Tilley et al 1999; McLennan \& Parminter 2004; Slater \& Radford 2012; Philips-Ryder et al 2013), Saudi Arabia (Darwish 2005), Japan (Minato 2003) and the UK (Laryea 2011).

Similarly in South Africa, Malinda (2017) explored the association between project documentation and the project outcomes linked to quality, cost and time. The findings of the research suggested that a positive correlation existed between good quality project documentation and positive project outcomes. The study further identified lack of resources due to low fees, inexperienced consultant personnel and a shortage of skilled staff as the top three out of seven factors suggested as contributing to the poor quality of project documentation.

Furthermore, a number of studies focused on South Africa have identified that poor quality design documentation contributes to inefficiencies in construction projects, including rework (Simpeh et al 2011; CIDB 2011; Emuze 2012), project delays (Baloyi \& Bekker 2011; Ramabodu \& Verster 2013), cost overruns (Baloyi \& Bekker 2011; Ramabodu \& Verster 2013) and low productivity (Bierman et al 2016).

Despite this, none of the above studies have specifically focused on or undertaken empirical research on the perceived quality of design documentation and the factors that influence this quality in the South African context. The broader scope of this ongoing research seeks to address this gap. Specifically, the aim of the research described in this paper is to identify the key factors that influence the quality of design documentation in South Africa.

\section{DESIGN DOCUMENTATION QUALITY}

The International Standards Organisation defines quality as the degree to which a set
JOURNAL OF THE SOUTH AFRICAN INSTITUTION OF CIVIL ENGINEERING ISSN 1021-2019 Vol 60 No 3, September 2018, Pages 41-48, Paper 0129

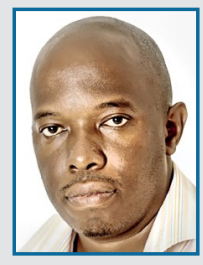

EMMANUEL AKAMPURIRA (PrEng, MSAICE) works as a civil engineer and is an Executive Associate at Kantey and Templer Consulting Engineers. He holds a Master's degree (Construction Economics and Management) from the University of Cape Town (UCT) and a Bachelor's degree (Civil Engineering) from Makerere University in Kampala, Uganda. He is the chairperson of the SAICE Western Cape Branch Committee and is passionate about research in the area of construction management. He is currently pursuing a PhD (Construction Economics and Management) at UCT.

Contact details:

Department of Construction Economics and Management

University of Cape Town

Private Bag X3

Rondebosch 7701

South Africa

T: +27214059600

E:akampsemma@yahoo.com

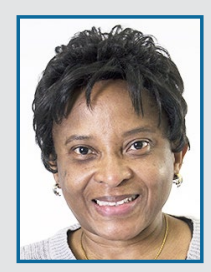

PROF ABIMBOLA WINDAPO is an Associate Professor in the Department of Construction Economics and Management, University of Cape Town, and has more than 30 years' teaching, research and construction industry experience. She is a Professional Construction Project Manager and Mentor registered with the South African Council for the Project and Construction Management Professions (SACPCMP) and is registered with the Council of Registered Builders of Nigeria. Her research focuses on construction industry development, business and project management. She is the Director of the Construction Business and Management Research Group, and editor of the Journal of Construction Business and Management.

Contact details:

Department of Construction Economics and Management

University of Cape Town

Private Bag X3

Rondebosch 7701

South Africa

T: +27216502049

E:abimbola.windapo@uct.ac.za 
Table 1 Quality attributes for design documentation (Tilley et al 1997; Minato 2003)

\begin{tabular}{|c|c|}
\hline Quality attribute & Definition \\
\hline Timeliness & Supplied when required to avoid delays. \\
\hline Accuracy & Free of errors. \\
\hline Completeness & Provides all the required information for construction. \\
\hline Coordination & Thoroughly coordinated between design disciplines. \\
\hline Clarity & Drawings and other documents are legible and easily interpreted. \\
\hline Conformance & Meets the requirements of performance standards and statutory regulations. \\
\hline Consistency & Drawings and other documents are consistent. \\
\hline Standardisation & $\begin{array}{l}\text { Makes use of standard details and specifications in drawing and other } \\
\text { documents. }\end{array}$ \\
\hline Relevance & Trade specifications and details are specific, relevant and appropriate to the project. \\
\hline Representation & $\begin{array}{l}\text { Drawings and other documents correctly represent the geological (subsurface) } \\
\text { and topography (surface) conditions, including existing utilities and structures. }\end{array}$ \\
\hline
\end{tabular}

of inherent characteristics fulfil requirements (ISO 2005). Within the context of this research, design documentation is a product of the design process, and the contractor is the user of this product. Therefore the quality of design documentation can be gauged by the degree to which it embeds the desired characteristics (attributes) necessary to meet the requirements of the contractor.

Some researchers (Tilley et al 1997; Minato 2003) have suggested quality attributes/indicators for design documentation. These attributes and their definitions are summarised in Table 1.

\section{Factors that influence the quality of design documentation}

A comprehensive literature review identified a number of studies that have reported on the factors that affect the quality of design documentation (Love \& Li 2000; Minato 2003; McLennan \& Parminter 2004; Darwish 2005; Love et al 2006; Abdalaziz 2009; Philips-Ryder et al 2013). A previous paper by the present authors (Akampurira \& Windapo 2016) highlights and briefly discusses the factors that were identified and included in this study.

A summary of the identified factors is provided in Table 2. Thirty-four factors influencing the quality of design documentation were identified from the literature and grouped into four categories, namely Client [11], Design firm [9], Industry [4] and Design professional [10].

The factors identified in Table 2 were incorporated into a questionnaire used to collect primary data as part of an empirical investigation. The following sections of this paper present the questionnaire development process, data collection and findings from the statistical analysis of the data received.

\section{METHODOLOGY}

\section{Questionnaire design}

A quantitative approach was adopted involving the use of a web-based questionnaire which incorporated the findings from the literature review and targeted civil engineering consultants. The questionnaire had five sections addressing different aspects of design documentation quality. The questions were a mixture of both open-ended and Likert-type scale questions.

The questionnaire was pilot-tested for clarity, suitability and appropriateness of the questions. Three practicing civil engineers, one contractor and one academic participated in the pilot test. Revisions were made to the wording of certain questions and general formatting to enhance the flow of the questionnaire. The industry-based practitioners proposed three additional factors that could influence the quality of design documentation:

1. Discounting of professional fees to below the recommended fee as per professional body (ECSA) guidelines.

2. Limited opportunity for new entrants into the profession to gain relevant experiential training.

3. Delays in payment of professional fees by clients.

The additional factors reflect issues that are probably unique to the South African construction environment (Lawless 2005; Maritz 2012; Windapo \& Cattell 2013; CESA 2016) and thus not necessarily picked up in the referenced studies that have been conducted predominately outside of South Africa.

Section A of the questionnaire collected demographic information about the respondents. Section D, consisting of 37 factors, sought to solicit the respondents' perceptions of the extent of influence the identified factors had on the quality of design documentation. The factors were categorised into four constructs, namely Industry, Client, Design Professional and Design Firm related factors. The respondents were requested to rate on a scale of 1 to 5 their assessment of the level of influence $(1=$ not influential at all, $2=$ slightly influential, 3 = somewhat influential, $4=$ very influential, 5 = extremely influential). This paper reports on and analyses the responses to these two sections of the questionnaire.

\section{Method of data collection}

The target population for data collection was civil engineers working in firms that are members of Consulting Engineers South Africa (CESA). On civil engineering projects, the civil engineers often perform the functions of design, project management and construction supervision. They are therefore well positioned to comment on the various aspects of design documentation. CESA is the leading umbrella organisation for consulting engineers, and its membership database is publicly accessible (CESA 2017). Firms operating in Gauteng, KwaZulu-Natal and Western Cape provinces were selected from the database. The selection of provinces was based on the fact that a significant amount of the construction activity in South Africa takes place in these provinces.

Four hundred and seventy-seven (477) firms were identified from the CESA database. In instances where a company had more than one registered office in a province, only the office registered as the head office was selected for inclusion in the survey. This was necessary to facilitate efficient management of the data collection process. Subsequently 371 firms met the inclusion criteria and were contacted to participate in the survey.

The web-based questionnaire was sent by e-mail to the contact addresses recorded on the CESA database. The cover e-mail briefly described the objectives of the research and provided a URL link to facilitate the online completion of the questionnaire. The request was that the questionnaire should 


\begin{tabular}{|c|c|c|c|c|c|c|c|c|c|c|}
\hline \multirow[b]{2}{*}{ Indicators/attributes } & \multicolumn{10}{|c|}{ Source } \\
\hline & 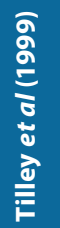 & 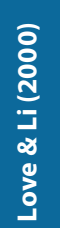 & 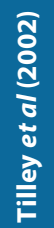 & 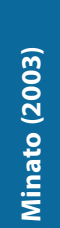 & 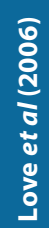 & 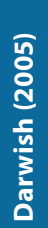 & 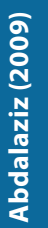 & 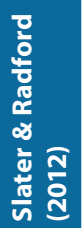 & 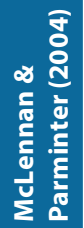 & 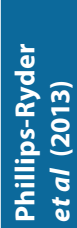 \\
\hline
\end{tabular}

Client (CR)

C1 Unrealistic client expectations regarding the time required for the design

C2 The quality of the project brief provided

C3 No specific person responsible for design coordination and providing information

C4 Client's lack of relevant project experience

C5 Numerous changes to client requirements

C6 Insufficient and missing information

C7 Provision of wrong information by the client

C8 Failure to review the design documentation

C9 Provision of conflicting information

C10 Unrealistic client expectations with respect to time required for construction

C11 Client's insistence to commence construction before completion of the detailed design phase

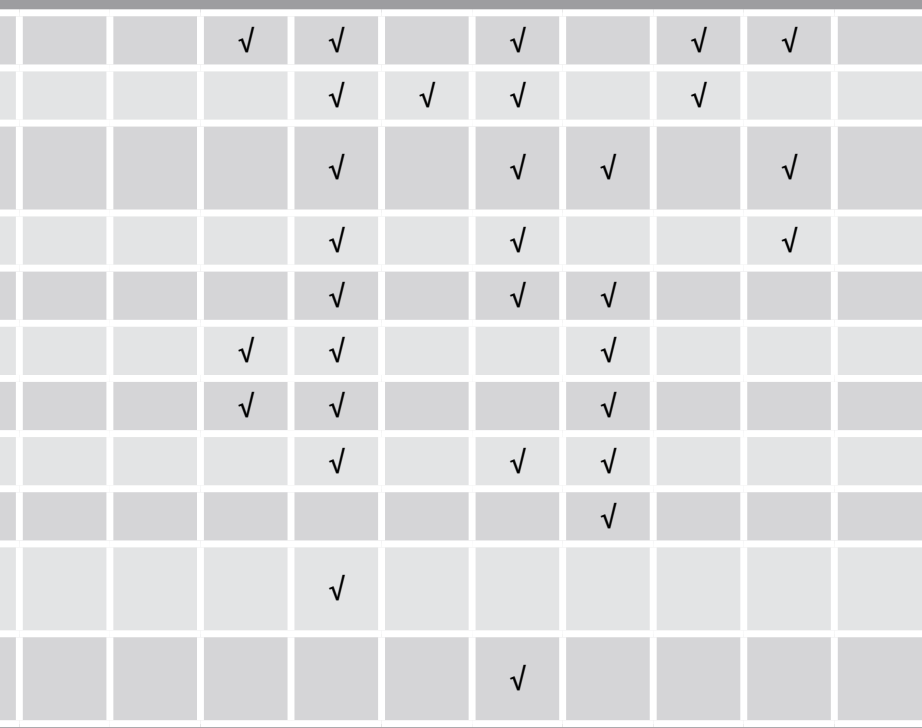

Design firm (DF)

\begin{tabular}{|c|l|}
\hline D1 & Lack of quality control practices and procedures \\
\hline D2 & Failure to adopt quality management systems, e.g. ISO 9001 \\
\hline D3 & Failure to provide relevant training to staff \\
\hline D4 & Inadequate design review processes \\
\hline D5 & Work overload on designers due to low staff levels \\
\hline D6 & Poor allocation of time in consideration of available workload \\
\hline D7 & Lack of relevant software \\
\hline D8 & High staff turnover \\
\hline D9 & Inadequate supervision of junior design staff \\
\hline
\end{tabular}

\begin{tabular}{|l|l|}
\hline V \\
\hline 10 \\
\hline
\end{tabular}


Industry (IR)

\begin{tabular}{|l|l|l|l|l|c|c|c|c|}
\hline E1 & Low design fees & $\sqrt{ }$ & $\sqrt{ }$ & $\sqrt{ }$ & $\sqrt{ }$ & $\sqrt{ }$ \\
\hline E2 & Selection of design firms based on lowest price tendered & & $\sqrt{ }$ & $\sqrt{ }$ & $\sqrt{ }$ & $\sqrt{ }$ \\
\hline E3 & Shortage of civil engineering skills & & $\sqrt{ }$ \\
\hline E4 & Low emphasis on professional standards & & $\sqrt{ }$ & $\sqrt{ }$ & $\sqrt{ }$ \\
\hline
\end{tabular}

Design professional (DR)

\begin{tabular}{|l|l|}
\hline F1 & The designer is inexperienced \\
\hline F2 & Lack of coordination between different design disciplines \\
\hline F3 & $\begin{array}{l}\text { Limited time available for checking and coordinating all design } \\
\text { documentation }\end{array}$ \\
\hline F4 & Improper use of design software \\
\hline F5 & $\begin{array}{l}\text { Reuse of design documents and details from previous projects } \\
\text { without adequate review }\end{array}$ \\
\hline F6 & Designer's unfamiliarity with construction techniques and materials \\
\hline F7 & The heavy workload on the designer \\
\hline F8 & Poor communication between multi-disciplinary teams \\
\hline F9 & Failure to understand the client brief \\
\hline F10 & Lack of experience on similar projects \\
\hline
\end{tabular}


be circulated among the civil engineering practitioners in the office.

Where possible, and to increase the number of responses to the questionnaire, the researcher made personal contact with individuals in the firm to encourage them to circulate the questionnaires among their colleagues. In addition, reminder e-mails were periodically sent to all respondents during the data collection period (November 2016 - January 2017).

The use of e-mails to deliver an online questionnaire presented certain challenges, which included bounced e-mails, undelivered e-mails, the inability to confirm if an e-mail had been delivered to the intended recipient's inbox, delivery of e-mails to junk mail folders and automatic filters/blocks in the recipient's e-mail settings. Bowen et al (2010) point out that these occurrences make it difficult to determine the response rates to online surveys. 129 questionnaires were returned, of which 91 had been completed. The completed questionnaires form the basis of the findings reported in this paper.

\section{Analysis of the data}

The survey data were analysed using the statistical analysis program SPSS 24 to obtain descriptive statistics. The reliability of the scale was tested for internal consistency using the Cronbach's coefficient alpha $\alpha$ (where $0 \leq \alpha \leq 1$ ). Internal consistency refers to the extent to which all the items on a scale measure the same construct (Tavakol \& Dennick 2011; Field 2013).

\section{Mean score}

The overall ranking of the influencing factors as perceived by the respondents was determined using the mean score (MS) of the Likert scale items (Chan et al 2003). The mean score is calculated using the formula

$\mathrm{MS}=\sum \frac{(\mathrm{f} \times \mathrm{s})}{\mathrm{N}}$

where

$\mathrm{f}=$ frequency of response to each rating (1-5) for each factor

$\mathrm{s}=$ score given to each factor by the respondents, ranging from 5 for extremely influential to 1 for not influential at all

$\mathrm{N}=$ number of responses to that factor.

\section{Kendall's coefficient of concordance}

Kendall's coefficient of concordance W $(0 \leq \mathrm{W} \leq 1)$ was used to evaluate the degree of agreement among the respondents on the ranking of the factors. A value of 0 indicates no trend of agreement among the respondents, while 1 shows total agreement or unanimity. The level of significance (p-value) associated with the test was used to establish whether the degree of agreement among the respondents on the ranking was consistent or not at a $5 \%$ significance level. The null hypothesis that there is no significant agreement among the respondents within the same group can be rejected when $\mathrm{W}$ is significant $(\mathrm{p}<0.05)$ (Siegel \& Castellan 1988; Field 2013).

\section{SURVEY RESULTS}

The following sections present the results of the data collected through an empirical survey. The analysis reported upon in this paper is based on 91 completed questionnaires received from civil engineers.

\section{Characteristics of the respondents}

\section{Role in the organisation}

The respondents' roles in the organisations were diverse and are reflected in Table 3. It can be seen from Table 3 that a significant number of the respondents (46.2\%) were design engineers. The respondents, by the nature of their role, would be intimately involved in the production and management of the design documents necessary for construction.

\section{Professional registration status}

Table 3 presents a summary of the professional registration status of the respondents. Professional registration is an indication of having achieved an acceptable degree of competence as assessed
Table 3 Respondents' profiles

Respondent characteristic

Respondent category

Consulting Engineers

Respondents' role in the organisation

\begin{tabular}{|l|r|r|}
\hline Design Engineer & 42 & 46.2 \\
\hline Engineering Project Manager & 29 & 31.9 \\
\hline Resident Engineer & 3 & 3.3 \\
\hline Technologist & 17 & 18.7 \\
\hline
\end{tabular}

Professional registration

\begin{tabular}{|l|l|l|}
\hline Registered & 69 & 75.8 \\
\hline Not registered & 22 & 24.2 \\
\hline
\end{tabular}

Professional registration category

\begin{tabular}{|l|r|r|}
\hline Pr Eng & 39 & 42.9 \\
\hline Pr Tech Eng & 21 & 23.1 \\
\hline Pr Eng \& Pr CPM & 6 & 6.6 \\
\hline Pr Tech Eng \& Pr CPM & 3 & 3.3 \\
\hline None & 22 & 24.2 \\
\hline
\end{tabular}

by other professionals in the industry (ECSA 2017). $75.8 \%$ of the respondents were professionally registered with the relevant professional bodies in the industry, specifically the Engineering Council of South Africa (ECSA) or the South African Council for Project and Construction Management Professions (SACPCMP). A percentage of the respondents, namely $9.9 \%$, were registered with both professional bodies.

\section{Years of experience}

Figure 1 presents the categorised years of experience of the respondents. It shows 
that the respondents' years of experience in the construction industry ranged from 2 to 40 years, with the average being 17.4 years. $81.3 \%$ of the respondents had more than 5 years' experience.

As a consequence, the information provided by the respondents was deemed reliable considering their roles, years of experience and professional registration status in the construction industry.

\section{Nature of projects}

The respondents based their responses to the factors that influence the quality of design documentations on a variety of civil engineering construction projects. The majority of these were completed predominately within the previous five years (92.3\%). This demonstrates that the projects referred to were carried out in the recent past, and this reduced the errors that could have arisen from a recall bias (Neuman 2014). These projects ranged from roads, urban civil infrastructure (e.g. stormwater, foul sewer) to mining works. Similarly, the construction project costs varied from R1 million to R2 billion. This illustrates that the responses were based on a variety of construction projects typical of the civil engineering construction industry in South Africa.

\section{Ranking of factors that influence the quality of design documentation}

The overall ranking of the factors that influenced the quality of design documentation as perceived by the respondents is presented in Table 4. This ranking is based on the calculated mean score. Each of the items on the scale attained a mean score of $\mathrm{MS} \geq 3$. " 3 " on the scale represented "somewhat influential." This implies that respondents perceived that all the identified factors influenced the quality of design documentation, albeit to varying degrees.

Cronbach's coefficient $\alpha$ was used to assess the internal consistency of the measurement scale. Cronbach's coefficient $\alpha \geq 0.7$ is an indicator of a reliable scale (Field 2013). The Cronbach's coefficient obtained for this survey was $\alpha=0.933$, which indicated that the measurement scale was internally consistent at the $5 \%$ significance level.

Table 4 shows that the key factors influencing the quality of design documentation on civil engineering projects are low design fees, selection of design firms according to the lowest price tendered, limited time available for checking and
Table 4 Overall ranking of factors that influence the quality of design documentation

\begin{tabular}{l}
\multicolumn{1}{c}{ Factor } \\
\hline Low design fees \\
Selection of design firms based on the lowest price offered \\
Limited time available for checking and coordinating all \\
design documentation \\
Discounting of professional fees to below the \\
recommended fee as per ECSA guidelines
\end{tabular}
Mean

4.494

Poor communication among multi-disciplinary teams

Unrealistic client expectations regarding time required for the design

Lack of coordination between different design disciplines

Numerous changes to client requirements

The level of quality of the project brief provided by the client

Inadequate design review processes

Unrealistic client expectations with respect to time required for construction

Designer's failure to understand the client brief

Client's insistence on commencing construction before completion of the detailed design phase

Designer is inexperienced
The heavy workload on the designer
Re-use of design documents and details from previous
projects without effective review by the designer

Lack of quality control practices and procedures in the generation of design documentation

Poor allocation of time, taking into consideration the current workload

Low emphasis on professional standards

Improper use of design software

No specific person on client team responsible for coordinating and providing the relevant information to the design team

Inadequate supervision of junior design staff

Shortage of engineering skills within the civil engineering industry

Designer's lack of experience on similar projects

Insufficient and missing input information from the client

Designer's unfamiliarity with construction techniques and materials

Provision of conflicting information by the client

Provision of wrong information by the client

Client's lack of relevant project experience

Low staff levels leading to work overload on designers

Failure to provide relevant training to staff

Client's failure to review the design documentation

Limited opportunity for new entrants into the profession to gain relevant experiential training

High staff turnover

Delays in payment of professional fees

Failure to adopt quality management systems, e.g. ISO 9001

Lack of relevant software to undertake the production of the design documentation

\section{Kendall's Coefficient of Concordance w}

Level of significance

Mean scores: $5=$ extremely influential, $4=$ very influential, $3=$ somewhat influential,
\[ 2 \text { slightly influential, } 1=\text { not influential at all } \]

Mean scores: $5=$ extremely influential, $4=$ very influential, $3=$ som
$2=$ slightly influential, $1=$ not influential at all

Rank Category

\begin{tabular}{l|l|l}
4.44 & 2 & Industry
\end{tabular}

4.378

4.352

4.319

4.297

4.256

4.256

4.231

4.176

4.154

4.121

4.110

4.099

4.044

4.033

4.022

4.011

3.967

3.967

3.956

3.955

3.945

3.934

3.934

3.934

3.911

3.901

3.868

3.824

3.747

3.697

3.549

3.516

3.300

3.253

3.099

0.127

0.000

Industry

Design professional

Industry

Design professional

Client

Design professional

Client

Client

Design firm

Client

Design professional

Client

14

Design professional

15 Design professional

16

Design professional

17

18

Design firm

Design firm

Industry

Design professional

Client

Design firm

Industry

Design professional

Client

Design professional

26 Client

27 Client

29

30

31

32

33

34

35

36

37

Design firm

Client

Industry

Design firm

Client

Design firm

Design firm

자.

(a)


coordinating all design documentation, discounting of professional fees to below the recommended fee as per ECSA guidelines and poor communication among multi-disciplinary teams.

Kendall's coefficient of concordance $\mathrm{W}$ for the overall ranking was $\mathrm{W}=0.127$, $\mathrm{p}<0.05$, therefore the null hypothesis that there is no significant agreement among the respondents within the same group can be rejected. This suggests that there was an acceptable degree of agreement among respondents regarding the ranking of the factors.

\section{DISCUSSION OF SURVEY RESULTS}

The respondents identified low design fee as the most important factor influencing the quality of design documentation in the South African construction industry. This is in agreement with Malinda (2017), who noted that lack of resources as a result of low fees contributed to the poor quality of the project documentation. This finding is also in line with the results reported in studies undertaken in Japan (Minato 2003) and Australia (Tilley et al 1999; Slater \& Radford 2012). It also supports the assertion by Bubshait et al (1998) that there is a strong correlation between low design fee and deficiencies in the design documentation. Project fees influence the allocation of resources, e.g. time and personnel dedicated to the project design process, and invariably the quality of the product of this process.

The emphasis on lowest price tendered as a selection criterion for professional service providers has been identified as a challenge in the South African construction industry (Weidemann 2014; CESA 2016). The results of this study reflect this concern in view of the high ranking assigned to the factor selection of design firms based on the lowest price tendered (ranked 2). Slater (2012) identified a similar challenge in the Australian sector, and as a mitigating measure, suggested that the quality and capabilities of the consultants should be included in the weighting during the selection process. The South African government has recently issued new procurement guidelines that seek to encourage the incorporation of quality criteria in addition to the existing price and preference criteria in the selection of professional service providers (SAICE 2016).

This study found that discounting of professional fees to below the recommended ECSA fee guidelines was ranked among the key factors that influence the quality of design documentation. The fee guidelines provide a benchmark and an approach to determining the appropriate professional remuneration that is required to provide a quality service (ECSA 2016). Research in South Africa indicates that the discounting of fees is prevalent in the industry and is driven by the procurement prescripts, which emphasise competition on the basis of price (Okonkwo 2014; Weidemann 2014; CESA 2016).

The late payment of professional fees has been identified as a significant concern in the South African construction industry (Maritz 2012; CESA 2016). In this study delay in payment of professional fees was ranked low (ranked 35 out of 37). This low ranking could be attributed to the fact that often at the design stage, the professional has an agreed fee that guides his allocation of resources. The late payment of fees manifests itself later on in the lifespan of the project and effectively only affects the cash flow of the business and not necessarily the resource allocations to the design task. This inference requires further investigation.

Respondents assigned a low degree of influence to the factor "Failure to adopt quality management systems, e.g. ISO 9001" (ranked 36). However, in interpreting this result, it is noted that all the respondents of this survey worked in CESA-registered firms where a quality management system is a prerequisite for membership. Further research might consider inclusion of companies that do not have a quality management system.

The respondents' relatively high ranking of the factor "Inadequate design review processes" at 10 was unexpected considering that the respondents' firms all had a quality management system in place. The design review process is an important aspect of the QMS and aims to provide an avenue for checking that the client requirements have been met (ISO 2005). While this ranking does not imply the absence of design review practices, it does suggest an area of weakness. Further research could be undertaken to establish how design reviews are conducted by engineering consulting firms in South Africa.

Shortage of engineering skills in the civil engineering industry was ranked relatively low at 23. By comparison, some industry reports in South Africa (Lawless 2005; Windapo \& Cattell 2013; Malinda 2017) have highlighted skills shortage as a challenge to the sector as a whole, which is especially evident in the client bodies and government departments. It is acknowledged that these studies did not focus specifically on the quality of design documentation; nevertheless their findings reflect the challenges in the industry. The low ranking might be explained by the fact that the survey did not involve respondents from the client bodies. Furthermore, it is probable that many of the respondents of this survey were not intimately involved with the staff recruitment process and thus were unable to relate to this factor as a direct challenge.

\section{SUMMARY AND CONCLUSION}

This research explored the relative importance of factors within the design process that influence the quality of design documentation in South Africa. Thirty-four factors were identified from a comprehensive literature review and formulated into a questionnaire. An additional three factors were proposed during the pilot testing phase of the questionnaire. The consolidated thirty-seven factors were incorporated into a final web-based questionnaire administered to South African civil engineering consultants practising in CESA member firms.

Analysis of the data collected shows that the following factors, presented in order of importance, have the greatest influence on the quality of civil engineering design documents: low design fees; selection of design firms by lowest price tendered; limited time available for checking and coordinating all design documentation; discounting of professional fees to below the recommended fee as per ECSA guidelines; and poor communication among multi-disciplinary teams. The following factors are considered to be the least influential: limited opportunity for new entrants into the profession to gain relevant experiential training; high staff turnover; delays in payment of professional fees; failure to adopt quality management systems, e.g. ISO 9001; and lack of appropriate software to produce the design documentation.

It is, however, necessary to recognise the limitations of this research. The CESA member firms' data bases were used to identify the survey respondents. These member firms are required to meet certain criteria (e.g. implementation of a quality management system) which may 
not be representative of all the consulting engineering practices in South Africa. Furthermore, the focus of the study was civil engineering projects. This guides the extent of generalisation of the results. Despite the aforementioned limitations, the findings from this research study offer insight into the relative importance of the factors within the design process that influence the quality of design documentation, and provide a basis upon which the South African construction industry can focus efforts aimed at identifying measures to improve the quality of design documentation and, as a consequence, the efficiency in the implementation of construction projects.

\section{ACKNOWLEDGEMENTS}

The authors gratefully acknowledge the time and input of all the respondents to the questionnaire. The authors would also like to express their appreciation for the support received from Kantey and Templer consulting engineers during the course of these studies.

\section{REFERENCES}

Abdalaziz, K 2009. Factors affecting the quality of design and contractual documents in Gaza Strip. Master's Dissertation. Islamic University of Gaza. Available at: http://library.iugaza.edu.ps/ thesis/87683.pdf.

Akampurira, E \& Windapo, A 2016. Conceptual framework of influencing factors for design documentation quality. In Windapo, A, Odediran, S \& Abdulrauf, A (Eds). Proceedings, 9th CIDB Postgraduate Conference on Emerging Trends in Construction Organisational Practices and Project Management Knowledge Area, 2-4 February, Cape Town, 102.

Baloyi, L \& Bekker, M. 2011. Causes of construction cost and time overruns: The 2010 FIFA World Cup stadia in South Africa. Acta Structilia, 18(1): 51-67. Bierman, M, Marnewick, A \& Pretorius, J 2016, Productivity management in the South African civil construction industry - factors affecting construction productivity. Journal of the South African Institution of Civil Engineering, 58(3): 37-44.

Bowen, P, Edwards, P, Cattell, K \& Jay, I 2010, The awareness and practice of value management by South African consulting engineers: Preliminary research survey findings. International Journal of Project Management, 28(3): 285-295.

Bubshait, A A, Al-Said, F A \& Abolnour, M M 1998, Design fee versus design deficiency. Journal of Architectural Engineering, 4(2): 44-4.6.
CESA (Consulting Engineers South Africa) 2016. Bi-annual economic and capacity survey. January June 2016 Available at: http:/www.cesa.co.za/sites/ default/files/CESA_BECS_Report_Jun16\%20(1). pdf.

CESA (Consulting Engineers South Africa) 2017. Home page (last update). Available at: https://www.cesa. co.za (accessed on 15 March 2017).

Chan, A P, Chan, D W \& Ho, K S 2003. An empirical study of the benefits of construction partnering in Hong Kong. Construction Management and Economics, 21(5): 523-533.

Chua, D, Kog, Y \& Loh, P 1999, Critical success factors for different project objectives. Journal of Construction Engineering and Management, 125(3): 142-150.

CIDB (Construction Industry Development Board) 2011. Construction quality in South Africa: A client perspective. Pretoria: CIDB.

Darwish, M I 2005. Factors affecting design and documentation quality in the construction industry. MSc Dissertation. Saudi Arabia: King Fahd University of Petroleum \& Minerals.

Davis, P R, Love, P E \& Baccarini, D 2009. Bills of quantities: Nemesis or nirvana? Structural Survey, 27(2): 99-108.

ECSA (Engineering Council of South Africa). 2017. ECSA: Why register? Available at: https://www.ecsa. co.za/register/SitePages/Why\%20Register.aspx (accessed on 22 April 2017).

ECSA (Engineering Council of South Africa) 2016. Guideline for Services and Processes for Estimating Fees for Persons Registered in terms of the Engineering Profession Act, 2000 (Act No.46 of 2000). Johannesburg: ECSA.

Emmitt, S 2007. Design Management for Architects. New York: Wiley.

Emuze, F 2012. Performance improvement in South African construction. PhD Thesis. Port Elizabeth: Nelson Mandela Metropolitan University. Available at: http://dspace.nmmu.ac.za:8080/xmlui/ bitstream/handle/10948/1642/FIDELIS\%20 ABUMERE\%20EMUZE.pdf? sequence=1.

Field, A 2013. Discovering statistics using IBM SPSS Statistics: and Sex and Drugs and Rock ' $n$ ' Roll, 4th ed. Los Angeles, CA: SAGE.

ISO (International Standards Organization) 2005. ISO 9000:2005. Quality Management Systems Fundamentals and Vocabulary. Geneva: ISO.

Laryea, S 2011. Quality of tender documents: Case studies from the UK. Construction Management and Economics, 29(3): 275-286.

Lawless, A 2005. Numbers \& needs: Addressing imbalances in the civil engineering profession. Midrand: SAICE.

Love, P E \& Li, H 2000. Quantifying the causes and costs of rework in construction. Construction Management E Economics, 18(4): 479-490.

Love, P E, Edwards, D J \& Smith, J 2006. Contract documentation and the incidence of rework in projects. Architectural Engineering and Design Management, 1(4): 247-259.

Malinda, M 2017. Quality of project documentation as a major risk source in infrastructure projects in South Africa. MEng (Civil Engineering) Dissertation. Stellenbosch University.

Maritz, M J 2012. What are the legal remedies available to contractors and consultants to enforce payment? Journal of the South African Institution of Civil Engineering, 54(2): 27-35.

McLennan, A \& Parminter, T 2004. Declining standards of project documentation quality in the building \& construction industry. A major challenge for all stakeholders. In: Hampson, K (Ed.). Proceedings, International Conference on Clients Driving Innovation, 25-27 October, Brisbane, Australia.

Minato, T 2003. Design documents quality in the Japanese construction industry: Factors influencing and impacts on construction process. International Journal of Project Management, 21(7): 537-546.

Neuman, W L 2014. Social Research Methods: Qualitative and Quantitative Approaches, 7th ed. Harlow, UK: Pearson Education.

Okonkwo, P N 2014. Consultant's risk: An investigation into the impact of discounted professional fees on the risk exposure of civil and structural engineering services consultants in South Africa. MEng Dissertation. Stellenbosch University. Philips-Ryder, M, Zuo, J \& Jin, X H 2013. Evaluating document quality in construction projects Subcontractors' perspective. International Journal of Construction Management, 13(3): 77-94.

Ramabodu, M S \& Verster, J J 2013. Factors that influence cost overruns in South African public sector mega-projects. International Journal of Project Organisation and Management, 5(1/2): 48-56.

SAICE (South African Institution of Civil Engineering) 2016. Focus on: National Treasury standard for infrastructure procurement and delivery management. Midrand: SAICE.

Siegel, S \& Castellan, J 1988. Nonparametric Statistics for the Behavioral Sciences, 2nd ed. New York: McGraw-Hill.

Simpeh, E K, Ndihokubwayo, R \& Love, P E 2011. Field diagnosis of causes and effects of rework in higher education residential facilities. Journal of Construction, 4(1): 17-24.

Slater, R \& Radford, A 2012. Perceptions in the Australian building industry of deficiencies in architects' design documentation and the effects on project procurement. Australasian Journal of Construction Economics and Building, 8(1): 23-33.

Tavakol, M \& Dennick, R 2011. Making sense of Cronbach's alpha. International Journal of Medical Education, 2: 53.

Tilley, P, McFallan, S L \& Sinclair, R G 2002. Improving design and documentation quality. CIB Report, 361-380. 
Tilley, P, McAllen, S L \& Tucker, S 1999. Design and documentation quality and its impact on the construction process. In: Bowen, P \& Hindle, R (Eds). Proceedings, CIB W55 \& W65 Joint Triennial Symposium, 5-10 September, Cape Town.

Tilley, P, Wyatt, A \& Mohamed, S 1997. Indicators of design and documentation deficiency. Proceedings, 5th Annual Conference of the International Group for Lean Construction, 16-17 July, Gold Coast, Australia, 137.
Wahedi, H 2016. Site practice: The role of design drawings within social communities. In: Chan, P \& Neilson, C

(Eds). Proceedings, 32nd Annual ARCOM Conference, Association of Researchers in Construction

Management, 5-7 September, Manchester, 2: 751-760.

Weidemann, W. 2014. On discounting and tendering. SAICE Civil Engineering, 22(2): 84.

Windapo, A O \& Cattell, K 2013. The South African construction industry: Perceptions of key challenges facing its performance, development and growth.
Journal of Construction in Developing Countries, 18(2): 65.

Yong, Y C \& Mustaffa, N E 2011. Clients, Consultants and Contractors' perception of critical success factors for construction projects in Malaysia. In: Egbu, C \& Lou, E C W (Eds). Proceedings, 27th Annual ARCOM Conference, Association of Researchers in Construction Management, 5-7 September, Bristol, UK, 735-744. 